\title{
A mild approach to synthesise enantiopure glycine-derived 5-phenylthiomorpholinone
}

Article

Accepted Version

Creative Commons: Attribution-Noncommercial-No Derivative Works 4.0

Monir, D. K. ORCID: https://orcid.org/0000-0001-9511-063X and Harwood, L. M. ORCID: https://orcid.org/0000-0002-84427380 (2021) A mild approach to synthesise enantiopure glycine-derived 5-phenylthiomorpholinone. Tetrahedron, 84. 132035. ISSN 0040-4020 doi:

https://doi.org/10.1016/j.tet.2021.132035 Available at https://centaur.reading.ac.uk/98350/

It is advisable to refer to the publisher's version if you intend to cite from the work. See Guidance on citing.

Published version at: http://dx.doi.org/10.1016/j.tet.2021.132035

To link to this article DOI: http://dx.doi.org/10.1016/j.tet.2021.132035

Publisher: Elsevier

All outputs in CentAUR are protected by Intellectual Property Rights law, including copyright law. Copyright and IPR is retained by the creators or other copyright holders. Terms and conditions for use of this material are defined in the End User Agreement.

\section{www.reading.ac.uk/centaur}

\section{CentAUR}


Central Archive at the University of Reading

Reading's research outputs online 


\section{Graphical Abstract}

\section{A mild approach to synthesise enantiopure glycine-derived 5-phenylthiomorpholinone}

Leave this area blank for abstract info.

Diana K. Monir ${ }^{\mathrm{a},{ }^{*}}$ and Laurence M. Harwood ${ }^{\mathrm{b}}$

a, ${ }^{*}$ Chemistry Programme, Faculty of Resource Science and Technology, University Malaysia Sarawak, 94300

Kota Samarahan, Sarawak, Malaysia, E-mail: mdkertini@unimas.my.Corresponding author.

${ }^{b}$ Department of Chemistry, School of Chemistry, Food and Pharmacy, University of Reading, Whiteknights,

Reading, Berkshire, RG6 6DX, UK. E-mail: 1.m.harwood@ reading.ac.uk .

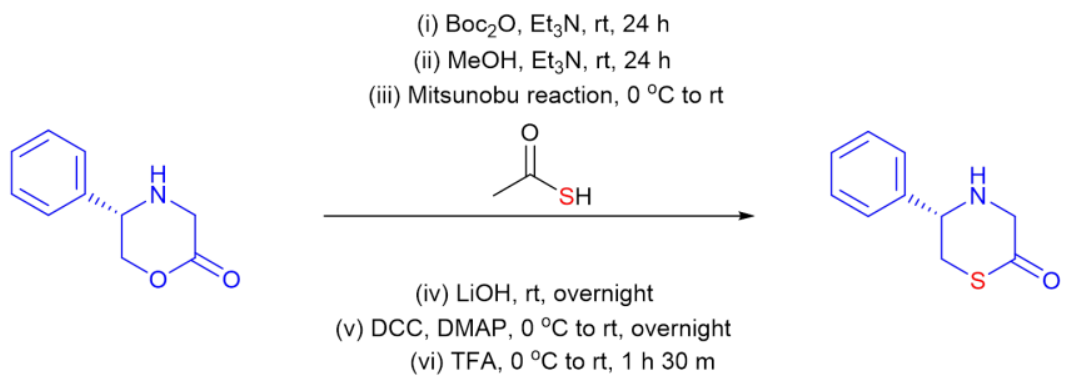




\title{
A mild approach to synthesise enantiopure glycine-derived 5-phenylthiomorpholinone
}

\author{
Diana K. Monir ${ }^{\mathrm{a},{ }^{*}}$ and Laurence M. Harwood ${ }^{\mathrm{b}}$

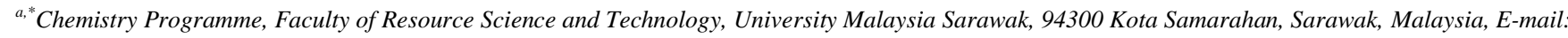 \\ mdkertini@unimas.my.Corresponding author.

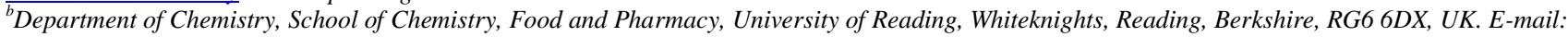 \\ l.m.harwood@ reading.ac.uk.
}

\section{ARTICLE INFO}

\section{Article history:}

Received

Received in revised form

Accepted

Available online

\section{Keywords:}

Thiomorpholinone;

Peptide coupling;

Mitsunobu reaction;

Ring sulfur installation

\section{ABSTRACT}

\begin{abstract}
A seven-step synthetic route has been developed to access the labile C-3 unsubstituted 5phenylthiomorpholinone system for the first time. The key step involved the nucleophilic ring opening of Boc-phenylmorpholinone to give the corresponding methyl ester. The sulfur introduction was accomplished through a Mitsunobu reaction to yield a thioacetate, which was then hydrolysed to provide the thiol acid. Cyclisation of the thiol acid was achieved using DCC in the presence of DMAP, to give Boc-phenylthiomorpholinone and subsequent deprotection afforded the elusive C-3 unsubstituted 5-phenylthiomorpholinone.
\end{abstract}

2009 Elsevier Ltd. All rights reserved.

\section{Introduction}

Peptide synthesis is limited to $C$ - to $N$-terminus direction in a linear extension protocol due to the epimerization problems associated with $C$-terminus activated, $N$-acylated amino acids. The Harwood group has discovered the possibility for peptide coupling in a manner similar to the way that Nature carries it out, namely in the $N$ - to $C$-terminus direction, based on the morpholinone template ${ }^{1}$ and two simple tripeptides, L-ala-L-ala-L-ala and L-alaD-ala-L-ala were successfully synthesized by adopting this approach in which the middle amino acid residue was synthesized de novo, followed by $N$-terminus extension and completed by $C$ terminus extension without epimerization of the $C$-terminus residue due to oxazalone formation being blocked. ${ }^{1,2}$

Central to this approach, it has been demonstrated that the $N$ acylated morpholinone ring can react with nucleophilic species, leading to opening of the lactone ring $^{1}$ and that the $\mathrm{N}$-acylated morpholinone could thus play the role of a $C$-terminus activated dipeptide that would prevent the formation of oxazolone and therefore epimerization of the activated amino acid. However, on increasing the steric bulk of the C-3 substituent of the morpholinone template, it was found that the aminolysis of the lactone ring was increasingly impeded. ${ }^{3}$

We proposed that the improved version of this system using a more electrophilic thiomorpholinone could widen its versatility in a peptide bond formation. Thiolactones are known to be more prone to nucleophilic attack than lactones. ${ }^{4}$ Therefore, a synthetic route to the novel thiomorpholinone analogues was developed in our group to investigate the reactivity of this system towards amide bond formation via thiolactone ring opening with the aim of finding milder and more efficient conditions for $C$-terminus extension. $^{4}$

Several 3(S)-R-5(R)-phenylthiomorpholinone derivatives possessing bulky substituents such as benzyl, iso-propyl, butyl and the less bulky methyl group have been successfully synthesized in a previous study in good overall yields that range from $62-86 \%$. This motif was developed based on a three step procedure through the formation of a thioester and cyclization to an imine and enamine mixture, followed by reduction to the desired thiomorpholinones. ${ }^{4,5}$ This study also revealed that the thiolactone was readily attacked by nucleophilic solvents such as methanol, a process that did not occur in the morpholinone system. The greater tendency of this template towards nucleophilic attack lent support to the proposal that the thiomorpholinone template could facilitate amide bond formation and improve the $C$-terminus extension for peptide coupling reaction.

However, the synthesis of the glycine-derived, C-3 unsubstituted thiomorpholinone $\mathbf{1}$ could not be achieved through the procedure developed to prepare 3,5-disubstituted thiomorpholinones. Although the cyclization to the mixture of imine and enamine isomers was successful, the final reduction step to the C-3 unsubstituted thiomorpholinone was found to be 
impossible, despite many attempts being carried out. ${ }^{6}$ All attempts led either to the thiomorpholinone dimer or decomposition. ${ }^{6}$

At this stage, it was therefore decided to focus on developing an alternative synthetic route to obtain the C-3 unsubstitutued glycine thiomorpholinone $\mathbf{1}$ as the absence of substitution at C-3 appeared to render the parent thiomorpholinone template highly susceptible to nucleophilic ring opening. Thus, we report herein an alternative synthetic approach to access glycine-derived, C-3 unsubstituted thiomorpholinone $\mathbf{1}$.

\section{Result and Discussion}

It was planned to use monosubstituted $5(S)$ phenylmorpholinone 7 as the initial precursor for conversion to $5(S)$-phenylthiomorpholinone $\mathbf{1}$. The starting material 7 was prepared and protected with a Boc group by the standard procedure described by Dellaria and Santarsiero. ${ }^{7}$ The condensation of phenylglycinol and phenylbromoacetate gave pure phenylmorpholinone at $70 \%$ yield. The $\mathrm{N}$-protection of 7 was performed immediately to avoid any loss due to dimerization. Bocprotected morpholinone $\mathbf{2}$ gave broadened signals on its room temperature $400 \mathrm{MHz}$ NMR spectrum due to restricted rotation of the acyl group attached to the nitrogen. An attempt at spectroscopic characterization at elevated temperatures up to to 85 ${ }^{\circ} \mathrm{C}$ was able to improve the appearance of the spectrum, leading to the signals becoming more, but not totally, resolved.

At $85{ }^{\circ} \mathrm{C}$, the broad signals centred at $\delta 4.64 \mathrm{ppm}$ and $\delta 4.48$ $\mathrm{ppm}^{7}$ for 2 were simplified into two double doublets at $\delta 4.64 \mathrm{ppm}$ $\left(J=8.0 \mathrm{~Hz}, J^{\prime}=4.0 \mathrm{~Hz}\right)$ and $\delta 4.47 \mathrm{ppm}\left(J=12.0 \mathrm{~Hz}, J^{\prime}=4.0 \mathrm{~Hz}\right)$ and the broad resonance centred at $\delta 5.05 \mathrm{ppm}$ became a broad triplet resonating at $\delta 5.05 \mathrm{ppm}(J=4.0 \mathrm{~Hz})$ corresponding to the $\mathrm{ABX}$ system for the protons at C-5 and C-6. Two doublets were also observed centred on $\delta 4.43 \mathrm{ppm}(J=12.0 \mathrm{~Hz})$ and $\delta 4.31 \mathrm{ppm}$ $(J=12.0 \mathrm{~Hz})$, indicating the presence of the AB system at C-3. All $\mathrm{ABX}$ and the $\mathrm{AB}$ protons of $\mathbf{2}$ were shifted downfield from the parent compound $\mathbf{7}$ due to the deshielding effect of the Boc group. The key step for the next stage was the lactone ring opening. This step posed a great challenge as the chosen reagent should be able to cleave the ester without removing the protecting group. Our
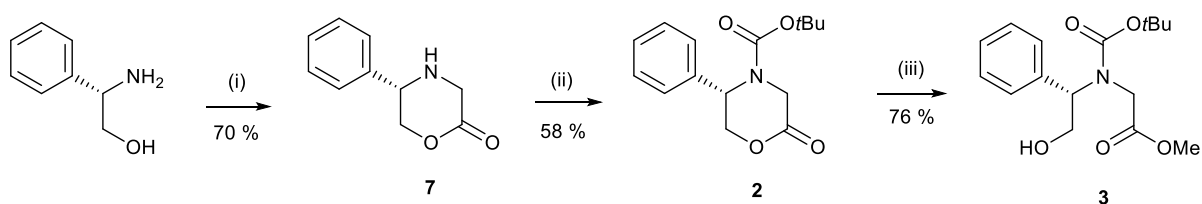

For the sulfur introduction in the next step, we were considering an approach that would not require any heating as our previous work had indicated that the Boc group could not withstand high temperatures in this system. Thus, with $\delta$-hydroxy methyl ester $\mathbf{3}$ in hand, we decided to apply a Mitsunobu reaction procedure to attempt to prepare the $\delta$-thioacetate methyl ester at temperatures from $0{ }^{\circ} \mathrm{C}$ to room temperature (Scheme 1). ${ }^{12}$ Treatment of $\delta$ hydroxyl methyl ester $\mathbf{3}$ with thioacetic acid, in the presence of triphenylphosphine and diisopropylazodicarboxylate (DIAD) afforded thioacetate methyl ester $\mathbf{4}$ as a yellow oil in $40 \%$ yield initial attempts at opening the morpholinone 2 template with
benzyl mercaptan and installing sulfur in one go by adapting Lumma's methodology failed. ${ }^{8}$ Therefore, we decided to change strategy by converting the protected morpholinone to the ringan adaption of Corey's methodology. ${ }^{9}$ With a large excess of methanol, the nucleophilic ring opening was carried out at room emperature for 24 hours in the presence of 6.0 equivalents of thylamine to give crude $\delta$-hydroxy methyl ester $\mathbf{3}$ as a silica chromatography gave slightly impure 3 in $~ 76 \%$ yield along with some starting material being recovered (Scheme 1). The methanolysis of 2 was then extended from 24 hours to 48 hours and 72 hours, with the reaction being monitored by ${ }^{1} \mathrm{H}$ NMR ectroscopy, based on the decrease of the proton resonance in 2 no significant change in the ratio of $\mathbf{2}$ and $\mathbf{3}$ over that period of time suggesting that both $\mathbf{2}$ and $\mathbf{3}$ exist in equilibrium under these conditions. This conclusion is supported by work of Kashima and Harada, who reported that several morpholin-2-one derivatives the methyl ester, by increasing the degree of ring substitution, most likely an illustration of the Thorpe-Ingold effect. ${ }^{10,11}$

The partial success of ring opening resulting in conversion to $\delta$-hydroxy methyl ester $\mathbf{3}$ was indicated by a singlet appearing at $\delta$ $3.58 \mathrm{ppm}$ revealing the presence of the methyl ester and this was absorption centred on $3486 \mathrm{~cm}^{-1}$ in the IR spectrum, corresponding to the free alcohol, gave further support for the formation of $\mathbf{3}$.

(n)

(


after 24 hours. The reaction required anhydrous THF and an inert atmosphere for the DIAD to be reduced and this could be observed when a milky mixture was formed after about 15 minutes. Separation of thioacetate methyl ester 4 from the triphenylphosphine oxide and hydrazine side products was best achieved by column chromatography and slow elution with hexane - ethyl acetate $(7: 1)$. In the beginning, it proved difficult to separate $\mathbf{4}$ from triphenylphosphine oxide as both compounds had similar Rf values of 0.3 and 0.4 respectively in hexane - ethyl acetate $(4: 1)$. Trituration with dichloromethane and hexane to precipitate triphenylphosphine oxide followed by purification through column chromatography using hexane - ethyl acetate (4 : 1) were also tried, but 4 could only been obtained in very poor yield and purity. Fortunately, chromatography on silica using the less polar solvent combination of hexane - ethyl acetate $(7: 1)$ successfully afforded pure $\mathbf{4}$ as a yellow oil in a yield of $40 \%$. However, prior to carrying out the column chromatography, the crude product required around $20-25$ minutes for complete dissolution in dichloromethane before loading onto the column. Heating to speed up the dissolution rate did not help as a white precipitate would then form on top of the column during elution, rendering the column ineffective.

A singlet observed at $\delta 2.33 \mathrm{ppm}$ in the ${ }^{1} \mathrm{H}$ NMR spectrum signified the presence of an acylthio group in 4. An ABX system was indicated by the presence of a broadened triplet at $\delta 5.54 \mathrm{ppm}$ $(J=8.0 \mathrm{~Hz})$ and a broad resonance integrating to two protons at $\delta$ $3.44-3.38 \mathrm{ppm}$. Two signals resonating at $\delta 3.79 \mathrm{ppm}(J=16.0$ $\mathrm{Hz})$ as a doublet and at $\delta 3.56 \mathrm{ppm}(J=16.0 \mathrm{~Hz})$ as a broad doublet could be assigned to the $\mathrm{AB}$ system of 4 . From the ${ }^{1} \mathrm{H}-{ }^{1} \mathrm{H}$ COSY NMR spectrum, there were correlation peaks among the $A B X$ protons as well as between the $\mathrm{AB}$ protons indicating these couplings more clearly. Finally, mass spectrometry confirmed the structure with mass ions observed at $368.1524\left[\mathrm{MH}^{+}\right]$and $390.1346\left[\mathrm{MNa}^{+}\right]$, matching with the desired thioacetate methyl ester 4.

The thioacetate methyl ester $\mathbf{4}$ was then hydrolysed with lithium hydroxide in aqueous iso-propanol under an atmosphere of nitrogen overnight to give crude thiol acid 5 (Scheme 1). The purification of crude thiol acid was carried out by chromatography on silica, eluting with hexane - ethyl acetate $(4: 1)$ with the addition of $1 \%$ formic acid to the solvent system to facilitate elution of the relatively polar thioacid (TLC Rf value of 0.2 in this solvent). With this procedure, thiol acid $\mathbf{5}$ was successfully obtained as a yellow oil in $69 \%$ yield. The absence of singlets at $\delta 2.33 \mathrm{ppm}$ and $\delta 3.61 \mathrm{ppm}$ in the ${ }^{1} \mathrm{H}$ NMR spectrum showed that the acyl and methoxy groups respectively had been completely removed. The ABX signals were detected at $\delta 5.28 \mathrm{ppm}(J=8.0$ $\mathrm{Hz})$ as a triplet and centred on $\delta 3.09 \mathrm{ppm}$ as a broad signal. Furthermore, two doublets at $\delta 3.63 \mathrm{ppm}(J=17.5 \mathrm{~Hz})$ and $\delta 3.55$ $\operatorname{ppm}(J=17.5 \mathrm{~Hz})$ could be assigned to the AB system of $\mathbf{5}$. Further evidence for mutual coupling within these $\mathrm{ABX}$ and $\mathrm{AB}$ multiplets was based on the correlations observed in the ${ }^{1} \mathrm{H}-{ }^{1} \mathrm{H}$ COSY NMR spectrum. All of this was consistent with the observation of a mass ion peak at $312.1264\left[\mathrm{MH}^{+}\right]$and $334.1084\left[\mathrm{MNa}^{+}\right]$corresponding to the desired product.

For the initial attempt to complete the final step of thiolactonization, we considered dicyclohexylcarbodiimide as the condensing agent. Other approaches for thiolacid ring closure using 10-camphorsulfonic acid or toluenesulfonic acid required heating to reflux at $110^{\circ} \mathrm{C}$, which could not be applied to our $N$ Boc protected compound. ${ }^{13,14}$ Over sixty years ago, Woodward et al. demonstrated that treatment of hydroxyacids with DCC in the presence of pyridine resulted in very effective conditions for lactonization. ${ }^{15,16}$ Furthermore, in 1969, Steglich and Höfle demonstrated that 4-dimethylaminopyridine (DMAP) was superior to pyridine. ${ }^{17}$ Therefore, the cyclization of thiol acid $\mathbf{5}$ was performed by reacting it with $\mathrm{DCC}$ in dichloromethane at $0{ }^{\circ} \mathrm{C}$ for 15 minutes before adding DMAP and leaving the mixture at room temperature overnight (Scheme 1). The formation of a white precipitate, presumed to be dicyclohexyl urea, was observed and the resulting mixture was filtered with suction through Celite ${ }^{\circledR}$, and the filtrate concentrated to give the crude cyclized product as a yellow oil. Purification of the crude product over silica, eluting with hexane - ethyl acetate ( $4: 1)$, afforded 6 as a yellow oil in 55 $\%$ yield.

As expected, Boc-protected thiomorpholinone $\mathbf{6}$ gave broadened signals on ${ }^{1} \mathrm{H} \mathrm{NMR}$ analysis at $400 \mathrm{MHz}$, once again requiring analysis at elevated temperature. A sample, dissolved in $\mathrm{DMSO} d_{6}$, was analysed from $25{ }^{\circ} \mathrm{C}$ to $85{ }^{\circ} \mathrm{C}$ at $500 \mathrm{MHz}$, with analysis at $85{ }^{\circ} \mathrm{C}$ giving a spectrum in which the resonances had become better defined although not fully resolved. At the higher temperature, the two broad $\mathrm{A}_{2} \mathrm{X}$ signals resonating at $\delta 5.02 \mathrm{ppm}$ and $\delta 3.65-3.56 \mathrm{ppm}$ in the $400 \mathrm{MHz}$ NMR spectrum were simplified into a broadened triplet at $\delta 5.14 \mathrm{ppm}(J=7.0 \mathrm{~Hz})$ and a broad doublet at $\delta 3.57(J=7.0 \mathrm{~Hz})$, integrating to one proton and two protons respectively. Two doublets at $\delta 4.52 \mathrm{ppm}(J=16.0$ $\mathrm{Hz})$ and $\delta 4.33 \mathrm{ppm}(J=16.0 \mathrm{~Hz})$ were also observed, corresponding to the $\mathrm{AB}$ system. The appearance of a resonance at $\delta 200 \mathrm{ppm}$ in the ${ }^{13} \mathrm{C}$ NMR spectrum that could be assigned to a thiolactone also suggested that the ring closure had occurred. This was further supported by strong overlapping absorptions around $1697 \mathrm{~cm}^{-1}$ in the infra-red spectrum signifying the presence of the thiolactone and Boc carbonyl groups. Final supporting evidence was obtained from the mass spectrum that showed a molecular ion at $316.0978\left[\mathrm{MNa}^{+}\right]$, also indicating that $N$-Boc-protected thiomorpholinone $\mathbf{6}$ had been successfully synthesized.

Removal of the Boc protecting group from Bocthiomorpholinone 6 was conveniently achieved using $50 \%(\mathrm{v} / \mathrm{v})$ trifluoroacetic acid in dichloromethane (Scheme 1). The desired 5phenylthiomorpholinone 1 was obtained as a yellow oil in $81 \%$ yield. The deprotection was also examined using $4 \mathrm{M} \mathrm{HCl}$ in dioxane as these conditions were reported to improve the yields of Boc removal and lead to shorter reaction times. ${ }^{18}$ However, this resulted in a lower yield (42\%), even though reaction was complete in 30 minutes to give the thiomorpholinone $\mathrm{HCl}$ salt.

The formation of $\mathbf{1}$ was verified by the presence of the thiomorpholinone characteristic resonances in the ${ }^{1} \mathrm{H}$ NMR spectrum, with two double doublets at $\delta 4.24 \mathrm{ppm}(J=11.0 \mathrm{~Hz}, J$, $=3.5 \mathrm{~Hz})$ and $\delta 3.19 \mathrm{ppm}\left(J=12.0 \mathrm{~Hz}, J^{\prime}=3.5 \mathrm{~Hz}\right)$ and a triplet at $\delta 3.48 \mathrm{ppm}(J=12.0 \mathrm{~Hz})$ corresponding to the ABX system. All three ABX protons were shifted upfield in comparison to the $N$ Boc precursor 6 . In addition, the two AB coupled protons had also shifted upfield to $\delta 3.86 \mathrm{ppm}(J=17.5 \mathrm{~Hz})$ and $\delta 3.81 \mathrm{ppm}(J=$ $17.5 \mathrm{~Hz}$ ) due to the removal of the deshielding effect of the $N-$ Boc 
group. Furthermore, the IR spectrum showed a broad N-H stretching centred around $3320 \mathrm{~cm}^{-1}$, indicating the presence of a free secondary amine, and a single carbonyl stretching absorption at $1664 \mathrm{~cm}^{-1}$. Final evidence came from the mass spectrum, with a molecular ion observed at $194.0634\left[\mathrm{MH}^{+}\right]$and so we were able to conclude that the elusive glycine-derived thiomorpholinone $\mathbf{1}$ had at last been obtained. It is important to note that the $N$-protection was essential throughout the synthetic sequence to ensure the success of template preparation. This approach provides the first synthetic route to access the C-3 unsubstituted 5phenylthiomorpholinone template that can now be used as a key structural motif for convergent synthesis of peptides containing a glycine amino acid residue at the coupling site at either $\mathrm{C}$ - or $\mathrm{N}$ terminus.

\section{Conclusion}

In conclusion, a synthetic route to access the previously elusive C-3 unsubstituted thiomorpholinone template $\mathbf{1}$ has been developed for the first time, comprising seven steps from commercially available 2-amino-2-phenylethanol (five steps from the known $N$-Boc-protected morpholinone 2). Attempts at improvement of this developed pathway and the incorporation of a 5-(4-methoxyphenyl) group on the thiomorpholinone system are ongoing.

\section{Experimental section}

\section{General procedure}

All chemicals and reagents were purchased from Sigma-Aldrich, Alfa Aesar and Tokyo Chemical Industries. Acetonitrile was dried over $4 \AA$ molecular sieves and tetrahydrofuran was dried by distillation from sodium benzophenone ketyl. All ${ }^{1} \mathrm{H}$ NMR spectra were recorded either at $400 \mathrm{MHz}$ on a Bruker Avance DPX400 spectrometer or at $500 \mathrm{MHz}$ on a Bruker AVIII500 spectrometer. ${ }^{13} \mathrm{C}$ NMR spectra were recorded at $100 \mathrm{MHz}$ on the first spectrometer. NMR solvents used were chloroform- $d$ and dimethyl sulfoxide- $d_{6}$. Spectra are reported on the $\delta$ scale referenced to tetramethylsilane (TMS). The abbreviations $s, d, t$, $\mathrm{m}, \mathrm{dd}, \mathrm{br}$, app are used to denote singlet, doublet, triplet, multiplet, double doublet, broad and apparent respectively. Infrared spectra were recorded on a Perkin-Elmer spectrometer in the frequency range $4000-400 \mathrm{~cm}^{-1}$. Mass spectrometry and accurate mass measurements (HRMS) were determined on a Thermo Scientific LTQ-Orbitrap-XL mass spectrometer using electrospray ionization (ESI). Specific rotations were determined on a PerkinElmer polarimeter at the sodium D line $(589 \mathrm{~nm})$. Melting points were determined with a Büchi melting point apparatus. Thin layer chromatography (TLC) analyses were performed using $0.25 \mathrm{~mm}$ thick silica gel $60 \mathrm{~F}_{254}$ plates in the appropriate solvent system. Compound visualization was carried out using a UV source at 254 $\mathrm{nm}$ and by staining with potassium permanganate solution. Column chromatography was conducted either using silica gel 60 (230-400 mesh).

\subsection{Synthesis of methyl (S)-N-(tert-butoxycarbonyl)-N-(2-hydroxy- 1-phenylethyl)glycinate (3)}

To a solution of $\mathrm{Et}_{3} \mathrm{~N}$ (6.99 g, $69.1 \mathrm{mmol}, 6.0$ equiv) in $\mathrm{MeOH}(50$ $\mathrm{mL}$ ) was added a solution of $2(3.19 \mathrm{~g}, 11.5 \mathrm{mmol}, 1.0$ equiv) in
$\mathrm{MeOH}(5 \mathrm{~mL})$. The reaction mixture was stirred for $24 \mathrm{~h}$ and then concentrated in vacuo to give a crude product that was purified over silica eluting with petroleum ether - diethyl ether $(1: 2)$ to afford ester $3(2.72 \mathrm{~g}, 76 \%)$ as a colourless oil. IR (ATR): $v_{\max }$ 3486, 3032, 2978, 1762, $1698 \mathrm{~cm}^{-1} .{ }^{1} \mathrm{H}$ NMR (400 MHz, DMSO $\left.d_{6}\right) \delta 7.40$ - $7.24(5 \mathrm{H}, \mathrm{m}, \mathrm{Ph}), 5.22(1 \mathrm{H}$, app t, $J=8.0 \mathrm{~Hz}, \mathrm{PhC} \underline{\mathrm{H}})$, $4.87-4.81\left(2 \mathrm{H}, \mathrm{m}, \underline{\mathrm{CH}}_{2} \mathrm{OH}\right), 3.91-3.84\left(2 \mathrm{H}, \mathrm{m}, \mathrm{CH}_{2} \mathrm{~N}\right), 3.58$ $\left(3 \mathrm{H}, \mathrm{s}, \mathrm{OCH}_{3}\right), 1.35$ (9H, bs, $t$-butyl). ${ }^{13} \mathrm{C} \mathrm{NMR}(100 \mathrm{MHz}, \mathrm{DMSO}$ $\left.d_{6}\right): \delta 170.9,154.3,138.6,128.1,79.4,60.6,51.6,45.5,27.9$. HRMS calcd for $\mathrm{C}_{16} \mathrm{H}_{24} \mathrm{NO}_{5}: 310.1654$ and $\mathrm{C}_{16} \mathrm{H}_{23} \mathrm{NO}_{5} \mathrm{Na}$ : 332.1474, found $310.1649\left(\mathrm{MH}^{+}\right)$and $332.1468\left(\mathrm{MNa}^{+}\right)$.

\subsection{Synthesis of methyl (S)-N-(2-(acetylthio)-1-phenylethyl)- $N$ - (tert-butoxycarbonyl)glycinate (4)}

DIAD (3.49 g, $17.3 \mathrm{mmol}, 2.0$ equiv) was added dropwise to a solution of triphenylphosphine (4.53 g, $17.3 \mathrm{mmol}, 2.0$ equiv) in dry tetrahydrofuran $(100 \mathrm{~mL})$ under an atmosphere of nitrogen at $0{ }^{\circ} \mathrm{C}$ for 30 minutes. A milky white mixture resulted. A solution of 3 (2.67 g, 8.64 mmol, 1.0 equiv) and thiolacetic acid (1.32 g, 17.3 mmol, 2.0 equiv) in dry tetrahydrofuran $(25 \mathrm{~mL})$ was then added dropwise and the stirring was continued for $1 \mathrm{~h}$ at $0{ }^{\circ} \mathrm{C}$ and the mixture then left overnight at room temperature resulting in a clear yellow solution. Ether $(25 \mathrm{~mL})$ was added and the solution was washed with water $(50 \mathrm{~mL})$, dried over $\mathrm{Na}_{2} \mathrm{SO}_{4}$, filtered and concentrated in vacuo. The crude product was purified by column chromatography, eluting with hexane - ethyl acetate $(7: 1)$ to give $4(1.28 \mathrm{~g}, 40 \%)$ as a yellow oil. IR (ATR): $v_{\max } 3029,2977,1756$, $1690 \mathrm{~cm}^{-1} .{ }^{1} \mathrm{H}$ NMR $\left(400 \mathrm{MHz}, \mathrm{CDCl}_{3}\right) \delta 7.33-7.30(5 \mathrm{H}, \mathrm{m}, \mathrm{Ph})$, $5.54(1 \mathrm{H}, \mathrm{t}, J=8.0 \mathrm{~Hz}, \mathrm{PhCH}), 3.79\left(1 \mathrm{H}, \mathrm{d}, J=16.0 \mathrm{~Hz}, \mathrm{CH}_{2} \mathrm{~N}\right)$, $3.61\left(3 \mathrm{H}, \mathrm{s}, \mathrm{OCH}_{3}\right), 3.56\left(1 \mathrm{H}\right.$, app d, $\left.J=16.0 \mathrm{~Hz}, \mathrm{CH}_{2} \mathrm{~N}\right), 3.44-$ $3.38\left(2 \mathrm{H}, \mathrm{bm}, \mathrm{CH}_{2} \mathrm{~S}\right), 2.33\left(3 \mathrm{H}, \mathrm{s}, \mathrm{CH}_{3} \mathrm{COS}\right), 1.44(9 \mathrm{H}, \mathrm{bs}, t-$ butyl). ${ }^{13} \mathrm{C} \mathrm{NMR}\left(500 \mathrm{MHz}, \mathrm{CDCl}_{3}\right): 195.4,170.7,154.9,152.9$, 129.0, 128.1, 126.2, 81.7, 72.4, 70.6, 69.8, 28.4, 25.3, 21.9. HRMS calcd for $\mathrm{C}_{18} \mathrm{H}_{26} \mathrm{NO}_{5} \mathrm{~S}$ : 368.1532 and $\mathrm{C}_{18} \mathrm{H}_{25} \mathrm{NO}_{5} \mathrm{SNa}$ : 390.1351, found $368.1524\left[\mathrm{MH}^{+}\right]$and $390.1346\left(\mathrm{MNa}^{+}\right)$. $[\alpha]_{\mathrm{D}}{ }^{20}-10.4(c 0.3$, $\left.\mathrm{CHCl}_{3}\right)$.

\subsection{Synthesis of (S)-N-(tert-butoxycarbonyl)-N-(2-mercapto-1- phenylethyl)glycine (5).}

To a solution of 4 (1.16 g, $3.16 \mathrm{mmol}, 1.0$ equiv) in $i$-PrOH (80 $\mathrm{mL})$ was added dropwise a solution of lithium hydroxide $(0.53 \mathrm{~g}$, $12.6 \mathrm{mmol}, 4.0$ equiv) in water $(50 \mathrm{~mL})$ at room temperature under an atmosphere of nitrogen. The reaction mixture was then stirred at room temperature overnight. Water $(50 \mathrm{~mL})$ was then added and the $\mathrm{pH}$ of the mixture was adjusted to $\mathrm{pH} 5$ with $1 \mathrm{M} \mathrm{HCl}$. The aqueous mixture was extracted with ethyl acetate $(3 \mathrm{x} 100 \mathrm{~mL})$ and the combined organic extracts were dried over $\mathrm{Na}_{2} \mathrm{SO}_{4}$, filtered and concentrated in vacuo. Purification by column chromatography, eluting with hexane - ethyl acetate - formic acid ( $4: 1: 0.01)$ afforded $5(0.68 \mathrm{~g}, 69 \%)$ as a yellow oil. IR (ATR): $v_{\max }$ 3494, 3034, 2977, 1732, $1686 \mathrm{~cm}^{-1}$. ${ }^{1} \mathrm{H}$ NMR (400 MHz, DMSO $\left.d_{6}\right) \delta 7.35-7.27(5 \mathrm{H}, \mathrm{m}, \mathrm{Ph}), 5.28(1 \mathrm{H}, \mathrm{t}, J=8.0 \mathrm{~Hz}$, $\mathrm{PhCH}), 3.63\left(1 \mathrm{H}, \mathrm{d}, J=17.5 \mathrm{~Hz}, \mathrm{CH}_{2} \mathrm{~N}\right), 3.55(1 \mathrm{H}, \mathrm{d}, J=17.5 \mathrm{~Hz}$, $\left.\mathrm{CH}_{2} \mathrm{~N}\right), 3.09\left(2 \mathrm{H}, \mathrm{bm}, \mathrm{CH}_{2} \mathrm{SH}\right), 1.37$ (9H, bs, $t$-butyl). ${ }^{13} \mathrm{C} \mathrm{NMR}$ $\left(500 \mathrm{MHz}, \mathrm{CDCl}_{3}\right)$ : 173.4, 154.6, 137.7, 129.0, 128.4, 127.7, 81.3, 61.1, 45.3, 29.8, 28.4. HRMS calcd for $\mathrm{C}_{15} \mathrm{H}_{22} \mathrm{NO}_{4} \mathrm{~S}: 312.1270$ and $\mathrm{C}_{15} \mathrm{H}_{21} \mathrm{NO}_{4} \mathrm{SNa}$ : 334.1089, found 312.1264 $\left(\mathrm{MH}^{+}\right)$and 334.1084 $\left(\mathrm{MNa}^{+}\right)$. 
4.4 Synthesis of tert-butyl (S)-2-oxo-5-phenylthiomorpholine-4carboxylate (6)

DCC ( $0.45 \mathrm{~g}, 2.19 \mathrm{mmol}, 1.1$ equiv) was added to a solution of $\mathbf{5}$ $(0.62 \mathrm{~g}, 1.99 \mathrm{mmol}, 1.0$ equiv) in dichloromethane $(50 \mathrm{~mL})$ and the reaction mixture was stirred at $0{ }^{\circ} \mathrm{C}$ for 15 minutes. DMAP $(0.27 \mathrm{~g}, 2.19 \mathrm{mmol}, 1.1$ equiv) was then added and the mixture was left overnight at room temperature. Dicyclohexylurea, formed as a white precipitate, was removed by filtration, the filtrate was concentrated under reduced pressure and the residue purified over silica, eluting with hexane - ethyl acetate $(4: 1)$ giving $6(0.32 \mathrm{~g}$, $55 \%$ ) as pale yellow oil. IR (ATR): $v_{\max } 3029,2980,1697,1391$, $1156 \mathrm{~cm}^{-1}$. ${ }^{1} \mathrm{H}$ NMR $\left(500 \mathrm{MHz}\right.$, DMSO $\left.d_{6}, 85^{\circ} \mathrm{C}\right) \delta 7.35(5 \mathrm{H}, \mathrm{m}$, $\mathrm{Ph}), 5.14(1 \mathrm{H}$, app t, $J=7.0 \mathrm{~Hz}, \mathrm{PhC} \underline{\mathrm{H}}), 4.52(1 \mathrm{H}, \mathrm{d}, J=16.0 \mathrm{~Hz}$, $\left.\mathrm{CH}_{2} \mathrm{~N}\right), 4.33\left(1 \mathrm{H}, \mathrm{d}, J=16.0 \mathrm{~Hz}, \mathrm{CH}_{2} \mathrm{~N}\right), 3.57(2 \mathrm{H}$, br d, $J=7.0$ $\mathrm{Hz}, \mathrm{CH}_{2} \mathrm{~S}$ ), 1.26 (9H, s, $t$-butyl). ${ }^{13} \mathrm{C}$ NMR (500 MHz, DMSO $d_{6}$ ): 200.2, 154.7, 142.8, 129.0, 128.1, 127.8, 82.7, 58.1, 51.6, 28.2. HRMS calcd for $\mathrm{C}_{15} \mathrm{H}_{19} \mathrm{NO}_{3} \mathrm{SNa}$ : 316.0983, found 316.0978 $\left(\mathrm{MNa}^{+}\right) \cdot[\alpha]_{\mathrm{D}}^{20}-38.2\left(c 0.3, \mathrm{CHCl}_{3}\right)$.

\subsection{Synthesis of (S)-5-phenylthiomorpholin-2-one (1)}

To a solution of $6(0.3 \mathrm{~g}, 1.02 \mathrm{mmol}, 1.0$ equiv $)$ in dichloromethane $(5 \mathrm{~mL})$ was added TFA $(5 \mathrm{~mL})$ at $0{ }^{\circ} \mathrm{C}$ and the mixture stirred at room temperature for 2 hours. The reaction was monitored by TLC until the starting material was consumed. The resulting mixture was evaporated in vacuo, redissolved in dichloromethane $(5 \mathrm{~mL})$, washed with saturated aqueous $\mathrm{NaHCO}_{3}$ $(2 \mathrm{~mL})$ and brine $(2 \mathrm{~mL})$, dried over anhydrous $\mathrm{MgSO}_{4}$, filtered and concentrated under reduced pressure to give $\mathbf{6}$ as a yellow oil (0.16 g, $81 \%)$. IR (ATR): $v_{\max } 3320,2931,1664 \mathrm{~cm}^{-1} .{ }^{1} \mathrm{H}$ NMR $\left(400 \mathrm{MHz}, \mathrm{CDCl}_{3}\right) \delta 7.43-7.31(5 \mathrm{H}, \mathrm{m}, \mathrm{Ph}), 4.24(1 \mathrm{H}, \mathrm{dd}, J=$ $\left.11.0 \mathrm{~Hz}, J^{\prime}=3.5 \mathrm{~Hz}, \mathrm{PhCH}\right), 3.86\left(1 \mathrm{H}, \mathrm{d}, J=17.5 \mathrm{~Hz}, \mathrm{CH}_{2} \mathrm{CO}\right)$, $3.81\left(1 \mathrm{H}, \mathrm{d}, J=17.5 \mathrm{~Hz}, \mathrm{CH}_{2} \mathrm{CO}\right), 3.48\left(1 \mathrm{H}, \mathrm{t}, J=12.0 \mathrm{~Hz}, \mathrm{CH}_{2} \mathrm{~S}\right)$, $3.19\left(1 \mathrm{H}, \mathrm{dd}, J=12.0 \mathrm{~Hz}, J^{\prime}=3.5 \mathrm{~Hz}, \mathrm{CH}_{2} \mathrm{~S}\right), 2.04(1 \mathrm{H}, \mathrm{bs}, \mathrm{NH})$. ${ }^{13} \mathrm{C} \mathrm{NMR}\left(100 \mathrm{MHz}, \mathrm{CDCl}_{3}\right): \delta 198.2,141.7,129.0,128.3,126.3$, 58.5, 58.3, 36.8. HRMS calculated for $\mathrm{C}_{10} \mathrm{H}_{12} \mathrm{NOS}$ : 194.0640, found $194.0634\left(\mathrm{MH}^{+}\right) .[\alpha]_{\mathrm{D}}{ }^{20}-119\left(c 0.5, \mathrm{CHCl}_{3}\right)$.

\section{Acknowledgments}

Access to instrumentation in the University of Reading Chemical Analysis Facility is gratefully acknowledged.

\section{References and notes}

1. Harwood, L. M., Mountford, S. J. and Yan, R. J. Pept. Sci., 2009, 15, 14.

2. Harwood, L. M. and Yan, R., 2008, U.S. Patent No. WO 2008/0281075 $A l$. Washington, DC: U.S. Patent and Trademark Office.

3. Yan, R., PhD Thesis. University of Reading, 2006.

4. Drew, M. G. B., Harwood, L. M. and Yan, R. Synlett, 2006, 2006 (19), 3259-3262.

5. Harwood, L. M., Wellings, D. A. and Moody, J. D., 2012, U.S. Patent No. WO 2012/020231 Al. Washington, DC: U.S. Patent and Trademark Office.

6. Gu, R., Phd Thesis. University of Reading, 2016.

7. Dellaria, J. F. and Santarsiero, B. D. J. Org. Chem. 1989, 85, 3916-3926.

8. Lumma, W. C., Dutra, G. A. and Voeker, C. A., J. Org. Chem., 1970, 35, 3442-3444

9. Corey, E. J., Albright, J. O., Barton A. E. and Hashimoto, S. I. J. Am. Chem. Soc., 1980, 102, 1435-1436.
10. Kashima, C. and Harada, K. J. Org. Chem., 1989, 54, 789-792.

11. Beesley, R. M., Ingold, C. K. and Thorpe, J. F. J. Chem. Soc.,Trans., 1915, 107,1080-1106

12. Kerdesky, F. A. J., Schmidt, S. P., Holms, J. H., Dyer, R. D., Carter, G. W. and Brooks, D. W. J. Med. Chem., 1987, 30, 1177-1186.

13. Ferraris, D. V., Majer, P., Ni, C., Slusher, C. E., Rais, R., Wu, Y., Wozniak, K. M., Alt, J., Rojas, C., Slusher, B. S. and Tsukamoto, T. J. Med. Chem., 2014, 57, 243-247.

14. Stoermer, D., Vitharana, D., Hin, N., Delahanty, G., Duvall, B., Ferraris, D. V., Grella, B. S., Hoover, R., Rojas, C., Shanholtz, M. K., Smith, K. P., Stathis, M., Wu, Y., Wozniak, K. M., Slusher, B. S. and Tsukamoto, T. J. Med. Chem., 2012, 55, 5922-5932.

15. Woodward, R. B., Bader, F. E., Bickel, H., Frey, A. J. and Kierstead, R. W. Tetrahedron, 1958, 2, 1-57.

16. Fieser, L. F. and Fieser, M. Reagents for Organic Synthesis, John Wiley and Sons, Inc., New York, 1967.

17. Steglich, W. and Höfle, G. Angew. Chemie Int. Ed. Engl., 1969, 8, 981981.

18. Han, G., Tamaki, M. and Hruby, V. J. J. Pept. Res., 2001, 58, 338-341.

\section{Supplementary Material}

Provided. 